ISSN (print) 0867-2008 / ISSN (online) 239 I-75 I 2

DOI: http://dx.doi.org/10.12775/OM.2018.006

Anna K. Dulska*

Instituto Cultura y Sociedad

Universidad de Navarra

Ed. Bibliotecas

S-31009 Pamplona

Spain

adulska@unav.es

\title{
PRÆLATUS SIVE MAGNATUS: HOSPITALLER PRIORS AMONG THE ECCLESIASTICAL ELITES OF THE KINGDOM OF NAVARRE IN THE FOURTEENTH AND FIFTEENTH CENTURIES
}

\section{KEYWORDS}

history; the Middle Ages; military orders; Order of Saint John; Knights Hospitaller; Roncesvalles; Navarre; ritual communication

\begin{abstract}
Prelates or magnates? Spiritual or temporal lords? Scholars who study the relationship between the Order of Saint John and the monarchy usually ask these questions about the status of the Hospitaller priors among the elites in their respective realms. This paper aims to look into this matter in the Kingdom of Navarre in the Late Middle Ages. This issue became a bone of contention between the prior of Canons regular of Roncesvalles on the one hand and the prior of Saint John on the other as early as the sixteenth century. This feud and the arguments that both sides gave for and against their claim have been used as a starting point for examining the courtly position of Hospitaller priors during the preceding two hundred years. The present study is based on analysing records of royal ceremonies and acts that provide valuable information about ritual communication in public space, where precedence reflected not only the kingdom's symbolic, institutional order, but also set the stage for political action.
\end{abstract}

* ORCID: https://orcid.org/0000-0002-3350-52 I I 
$\mathrm{D}$ uring its entire medieval history - from the last will of King Alfonso I the Battler in I 34 to Emperor Charles V's concession of the island of Malta in I 530 , the Order of Saint John developed a symbiotic relationship with European monarchies. ${ }^{\text {I }}$ Patients who were provided with care in the Hospital of the Order at Rhodes prayed for secular princes:

"Let's pray for the King of France, of England and of Spain, for the five kings, for the King of Cyprus and the one of Armenia, for all kings, counts and barons, for poor and rich Christians of the West and the East". ${ }^{2}$

The Order needed support, privileges, exemptions and protection from rulers, who, besides pious prayers, expected more tangible profits in return. Thus, Hospitaller priors frequently acted as royal counsellors, diplomats and suppliers of

I Helen J. Nicholson, "Nolite confidere in principibus. The Military Orders' Relations with the Rulers of Christendom," in Élites et ordres militaires au Moyen Age. Rencontre autour d'Alain Demurger, ed. Philippe Josserand, Luís F. Oliveira, Damien Carraz (Madrid: Casa de Velázquez, 20I5), 26I-276; Kristjan Toomaspoeg, "Les ordres militaires au service des pouvoirs monarchiques occidentaux," in Élites et ordres militaires au Moyen Age. Rencontre autour d'Alain Demurger, ed. Philippe Josserand, Luís F. Oliveira, and Damien Carraz (Madrid: Casa de Velázquez, 2015), 32 I-332. The relationship between military orders and monarchies has been object of numerous studies; on Navarre see: Santos A. García Larragueta, "La Orden de San Juan de Jerusalén en Navarra. Siglo XIV," in Las órdenes militares en el Mediterráneo occidental (s. XII-XVIII). Coloquio celebrado los días 4, 5, 6 de mayo de I983, ed. Instituto de estudios manchegos (Ciudad Real, Espagne) and Casa de Velázquez (Madrid) (Madrid: Casa de Velázquez, I989 / Ciudad Real: Instituto de Estudios Manchegos, I989), I03-I 38 ; Carlos Barquero Goñi, "The Hospitallers and the Kings of Navarre in the Fourteenth and Fifteenth Centuries," in The Military Orders, vol. 2, Welfare and Warfare, ed. Helen J. Nicholson (Aldershot: Ashgate, I 998), 349-354; id., La Orden de San Juan de Jerusalén en Navarra: siglos XIVy $X V$ (Pamplona: Fundación Fuentes Dutor, 2004), 37-6r; id., "Los Hospitalarios y los últimos reyes de Navarra (1483-I I I 2)," in The Hospitallers, the Mediterranean and Europe. Festschrift for Anthony Luttrel, ed. Karl Borhardt, Nikolas Jaspert, and Helen J. Nicholson (Aldershot: Ashgate, 2007), 233-242; Julia Pavón Benito, "La relación entre monarquía y la Orden de San Juan de Jerusalén en Navarra (siglos XII-XV). Un primer análisis" in La Orden del Hospital de San Juan de Jerusalén. Contextos y trayectorias del Priorato de Navarra medieval, ed. Julia Pavón Benito and María Bonet Donato (Pamplona: Eunsa-CSIC, 20 I 3 ), I I I - I 77. An extensive bibliography on this subject can be found in: Anna K. Dulska, "Malitia temporis. Priorato navarro de la Orden de San Juan de Jerusalén bajo fray Martín Martínez de Olloqui (1383-1435)” (Unpublished Ph.D diss., Universidad de Navarra, 2016), 225-226.

- Preguem per lo rey de Fransa ed'Englaterra et d'Espanha- Et per los.V. reyes et per lo rey de Chipre et per aquel de Erminha et per totz los reyes et los comptes et baros, paures et ricx crestians qui sunt de Sa mar et de la y; see Ricardo Cierbide Martinena, Estatutos antiguos de la Orden de San Juan de Jerusalén: Versión original occitana y su traducción al español, según el códice navarro del AHN de Madrid (1314) (Pamplona: Gobierno de Navarra, I 999), I 34 (Occitan original), 207 (Spanish translation). 
military forces. Many prominent Hospitallers built impressive careers in the service of worldly lords and had to find ways to balance both loyalties, avoiding the dilemma of putting the interests of princes ahead of those of the Order or letting them take over a given priory. ${ }^{3}$

Studying the relationship between the Order of Saint John and monarchies from a functional point of view leads to a more transcendental query into the status that Hospitallers enjoyed among regional power elites. While the Order's place in the ecclesiastical arm as a religious-military order remained undisputed, Hospitaller priors' presence at royal courts may have brought into question their spiritual condition as prelates and they may rather have been seen as part of the secular estate of barons and knights - a condition they also possessed, after all. ${ }^{4}$ Assignment to one estate or another had serious implications for both the Order and the individual in terms of prestige, identity and capacity for political action. This paper aims to understand this matter in the Kingdom of Navarre during the Late Middle Ages.

Ritual communication in public space offers a valuable approach to address this issue. ${ }^{5}$ Consciously constructed by and binding for those in circles of pow-

3 Sophia Menache, "Elections in the Military Orders in the Late Middle Ages: an Achilles' Heel?" in Die Ritterorden als Träger der Herrschaft: Territorien, Grundbesitz und Kirche, ed. Roman Czaja and Jürgen Sarnowsky, Ordines Militares. Colloquia Torunensia Historica XIV (Toruń: Wydawnictwo Uniwersytetu Mikołaja Kopernika, 2007), i 42; Carlos Barquero Goñi, "La orden militar del Hospital y la monarquía castellana durante la Baja Edad Media," Meridies. Revista de Historia Medieval, no. 5-6 (2002): I 49-1 50; Zsolt Hunyadi, "Entering the Hospital. A Way to the Elite in the Fifteenth Century?" in Élites et ordres militaires au Moyen Age. Rencontre autour d'Alain Demurger, ed. Philippe Josserand, Luís F. Oliveira, and Damien Carraz (Madrid: Casa de Velázquez, 20 I 5), i 02 and I 10.

4 In England, priors were considered the main barons of the kingdom, see: Jürgen Sarnowsky, "Kings and Priors: the Hospitaller Priory of England in the later Fifteenth Century," in Mendicants, Military Orders and Regionalism in Medieval Europe, ed. Jürgen Sarnowsky (Aldershot: Ashgate, I 999), 85; Simon Phillips, The Prior of the Knights Hospitaller in Late Medieval England (Woodbridge: The Boydell Press, 2009), 100-102; 1 33 - I 36.

5 Gerd Althoff, Die Macht der Rituale: Symbolik und Herrschaft im Mittelalter (Darmstadt: Wissenschaftliche Buchgesellschaft, 2003), i 8-23 and passim. For further information on rituals and ritual communication in the Middle Ages, see: Gerd Althoff, Johannes Fried, Patrick J. Geary (eds.), Medieval Concepts of the Past: Ritual, Memory, Historiography (Cambridge: Cambridge University Press, 2002); Frances Andrews, "Ritual and Space: Definitions and Ways Forward," in Ritual and Space in the Middle Ages, ed. Frances Andrews (Donington: Shaun Tyas, 20 I I), I-29; Sergio Bertelli, The King's Body: Sacred Rituals of Power in Medieval and Early Modern Europe, trans. Robert Burr Litchfield (University Park: Penn State Press, 20 Io); Nils Holger Petersen, Mette Birkedal Bruun, and Jeremy Llewellyn, The Appearances of Medieval Rituals. The Play of Construction and Modification (Turnhout: Brepols, 2004); Sophia Menache, The Vox Dei. Communication in the Middle Ages (New York-Oxford: Oxford Uni- 
er, it established rules that regulated their static and dynamic positions in relation to the king. All active and passive attendees at public ceremonies understood these rituals and symbolic behaviours, helping to build trust and respect among them. One of the most tangible manifestations of medieval ritual communication is found in courtly precedence, which was reliably registered in records pertaining to royal ceremonies and acts. It is a source of valuable information on who was who at medieval court and aids in answering the question of the place of the Hospitaller prior - of Navarre in this case - among the realm's power elites.

\section{FeUding over a SEAT AT Cortes GENERALES}

The question of whether the Hospitaller priors of Navarre were spiritual or temporal lords is not merely scholarly. It was first posed in the early sixteenth century on the eve of the annexation of Navarre to Castile ( I 5 I 2), when it became a bone of contention between two of the most important ecclesiastical figures in the kingdom, namely the prior of Roncesvalles on the one hand, and the prior of Saint John on the other. ${ }^{6}$

The first episode of this feud started as early as 1499 when the prior of regular canons of the collegiate of Roncesvalles, Juan de Egües (I 454-I 500), and the prior of Saint John, Berenguer Sanz de Berrozpe ( 149 I - I 5 I 3 ), argued over which of them had the right to precede the other at Cortes Generales, which was to be held in the city of Pamplona. ${ }^{7}$ Cortes Generales, or simply Cortes, was a general assembly made up by the three estates of the kingdom, including the prelates or representatives of the dioceses and of the main monasteries, nobles (barons or ricoshombres, knights and minor nobility or hidalgos), and delegates of the cities and towns

versity Press, I 990); Edward Muir, Ritual in Early Modern Europe (Cambridge: Cambridge University Press, 2000); Dušan Zupka, Ritual and Symbolic Communication in Medieval Hungary under the Arpád Dynasty (I000-I30I) (Leiden: Brill, 20 I 6), I 5-34.

6 Javier Ibarra, Historia de Roncesvalles (Pamplona: Acción Social Tipografía, I 935), 387-390; Eloísa Ramírez Vaquero, "La comunidad regular de Santa María de Roncesvalles (siglos XII-XIX)," Príncipe de Viana, no. 199 ( 1993): 382 ; Barquero Goñi, La Orden de San Juan, 83-84.

7 Sentence pronounced by Princess Catherine of Navarre on behalf of her parents the King and the Queen of Navarre with regard to the feud between priors of Roncesvalles and Saint John, 9 December 1499, Madrid, Archivo Histórico Nacional (henceforth as: AHN), Órdenes Militares, Carp. 850, no. 32 (transcription can be found in Barquero Goñi, La Orden de San Juan, 300-302); Sentence pronounced by Cortes Generales of Navarre with regard to the feud between priors of Roncesvalles and Saint John, 9 December I 499, AHN, Órdenes Militares, Carp. 850 , no. 33 . 
of the realm, or buenas villas. ${ }^{8}$ The king convened them on the most important affairs, such as oaths to the heirs to the throne, declarations of war, reforms of the General Charter (Fuero General), the appointment of the regent or the imposition of extraordinary taxes.

The argument echoed a split of the Navarrese society into two factions, the Beaumonts and the Agramonts, which began in the fourteenth century, eventually led to a civil war ( I 45 I-1 464), and persisted afterwards. ${ }^{9}$ The prior of Roncesvalles, Juan de Egües, was adviser to the king and mediator in the feuds between both sides, ${ }^{10}$ while the prior of Saint John, Juan de Beaumont ( I 435-I 487), performed a key role in the conflict as the chancellor of the kingdom, adviser first to one side and then to the other, and of course as the leader of his faction ${ }^{11}$. In the middle of an intricate game of Hispanic thrones in which John II of Navarre and Aragon pulled strings, ${ }^{12}$ in 1469 the king replaced his daughter Eleanor as his lieutenant in Navarre with her son Gaston and appointed six dignitaries as the prince's counsellors, including one for the estate of the Church, one for the estate of knights, two for the estate of buenas villas and the marshal of the kingdom. ${ }^{13}$ The religious counsellor was none other than Juan de Egües, the prior of Roncesvalles and the military counsellor was none other than the prior of Saint John, Juan de Beaumont. This, in combination with the fact that the latter seemed to have little to no religious vocation, settled protocol for the following decades and it is very likely that this is what made the prior of Roncesvalles aspire to set de iure what, according to him, had already been in practice de facto. Unfortunately, the register of this first attempt does not reveal the arguments on either side. The sentence pronounced by Princess Catherine, daughter and lieutenant of the royal couple of John of Albret and Catherine of Foix (Gaston's daughter), together with the royal council, ruled that, despite the custom practiced across every kingdom that the prior of Saint John preceded all other dignities but the bishops, in consideration of

8 José María Lacarra, "Las Cortes de Aragón y de Navarra en el siglo XIV," Anuario de Estudios Medievales, no. 7 (1970-1 97 I ): 645-652; Javier Zabalo Zabalegui, La administración del reino de Navarra en el siglo XIV (Pamplona: Universidad de Navarra, I 973), 343-35 I.

9 Eloísa Ramírez Vaquero, Solidaridades nobiliarias y conflictos politicos en Navarra, 1387-I464 (Pamplona: Gobierno de Navarra, I 990), 2 I I-305; Jaume Vicens Vives, Juan II de Aragón (1398-1479): monarquia y revolución en la España del siglo XV. Edición de Paul H. Freedman y Joseph M. Muñoz i Lloret (Pamplona: Urgoiti, 2003), passim.

1o Ramírez Vaquero, "La comunidad," 379-380.

I Julia Pavón Benito, "Juan de Beaumont, prior del Hospital: promoción al cargo y control de la Orden por parte de una facción nobiliaria," Medievalismo, no. 25 (201 5):369-388.

12 Vicens Vives, Juan, part 2.

13 José María Lacarra, Historia politica del Reino de Navarra desde sus orígenes hasta su incorporación a Castilla, vol. 3 (Pamplona: Aranzadi, 1973), 326; Vicens Vives, Juan, 342. 
the person, the age and the authority of Juan de Egües, he was given the privilege of precedence during his lifetime. Upon his death, it was to be returned to Berenguer or his successor.

This decision, which the king and the queen later confirmed, ${ }^{14}$ did not really satisfy the prior of Roncesvalles for two reasons. First, it clearly stated that customary precedence belonged to Saint John. Second, Juan de Egües died the following year ( 1500 ) and the prior of Saint John did not delay in recovering his seat. Hence, in I 50 I, Juan de Egües's successor and nephew, Fernando de Egües ( I $500-$ - I 522 ), supported by the abbot of La Oliva Cistercian monastery, appeared before the monarchs to reinstate the case. The royal council gathered to hear both sides and carried out proceedings. ${ }^{15}$

The prior of Roncesvalles commenced his case by claiming that, since time immemorial, the ecclesiastical arm of the kingdom had a specific order, with the bishop of Pamplona at the head and, in his absence, the prior of Roncesvalles, followed by the abbot of La Oliva (hence his interest in the feud) and then the other prelates. However, to their surprise, the prior of Saint John infringed upon this order by taking the first seat among the clergy while he himself was not a professed clergyman, but rather a knight and a layman. Should the monarchs sanction this practice, they would offend their dignities. The arguments to back up his demand were as follows: Firstly, whenever clergymen and laymen gathered together, the former preceded the latter. Furthermore, not only had he not professed religious vows, but he did not wear the religious habit and dressed like a knight. Conversely, the pope granted the prior of Roncesvalles the prerogative to use bishopric insignia "from head to toe," including the crosier, the mitre, the ring and even the rochet, while the abbot of La Oliva could only use the crosier and the mitre. ${ }^{16}$ Secondly, he referred to the legal disposition that exempt prelates always precede non-exempt ones. In this case, the prior of Roncesvalles' only superior was the Pope, while the prior of Saint John was not only a subject of the grand master but,

${ }_{14}$ John III of Albret and Catherine of Foix, King and Queen of Navarre confirm the sentence proncounced by their daughter Catherine and Cortes Generales with regard to the feud between priors of Roncesvalles and Saint John, March I 500, AHN, Órdenes Militares, Carp. 850 , no. 34 .

is Feud over a seat at Cortes Generales between priors of Roncesvalles and Saint John, 28 January I 505, Roncesvalles, Archivo de la Real Colegiata de Roncesvalles, Dignidad Pr., Fajo Ú., o24, ref. Perg. 446.

16 What they did not mention, however, was that these prerogatives were limited within their respective communities, see: Colección diplomática de Santa María de Roncesvalles (II27-I300), ed. Ma Isabel Ostolaza (Pamplona: Institución Príncipe de Viana, I 978), nos. 27 (I 203 - the pope concedes the priors of Roncesvalles the use of rochet) and I 69 ( 1259 - the pope concedes the priors of Roncesvalles the use of mitre and ring); Ramírez Vaquero, "La comunidad," $37 \mathrm{I}$. 
recently and alluding to the civil war, was far too dependent on the royal family. Thirdly, once more Fernando invoked very old tradition, saying that if any prior of Saint John ever happened to sit among the clergy, he was to be the last. As proof, he mentioned the oath taken by Navarrese ambassadors in 1319 in Paris to Jeanne de Evreux and her spouse, Philip, as heirs to the throne, ${ }^{17}$ the coronation of Charles III the Noble in I 390, the amendment to the Charter (amejoramiento del Fuero) in I $4 \mathrm{I} 8$ and the coronation of King John, without specifying whether he was referring to John II (1429) or John of Albret (1 494). Finally, he stated that the argument that the prior of Saint John had precedence in other kingdoms was of no value because, in the kingdom of Navarre, "the truth is known from the written documents".

In his reply, the prior of Saint John expressed his astonishment that the new prior of Roncesvalles would attempt to contest the already existing and valid sentence on this matter, especially given that he had followed it to the letter out of respect for the former prior and the sentence itself. Berenguer then discredited Fernando's argument by saying that the Order of Saint John had preceded Roncesvalles in the ecclesiastical arm for centuries for a number of reasons. This was the case, for example, during the oath and coronation of Jeanne and Philip (I 328 ), of Charles (he did not specify whether he meant Charles II in I 350 or Charles III in I 390) and during the ceremony of the unification of the three burgs of Pamplona, known as the Privilege of Union (1423). Firstly, the monastic priors, even those with crosier and mitre, were beneath the prior of Saint John because the latter had power over commanders, knights, priests, and sergeants, and demanded their obedience through provincial chapters. Secondly, he stressed the condition of grand priors that Hospitaller regional leaders had in neighbouring kingdoms, such as France and Aragon where, moreover, the Castellan of Amposta, as the Aragonese prior was called, followed the bishop of Saragossa. Regarding religious vows, the prior of Saint John was both knight and a religious person because of the three vows every full member of the Order must profess. Furthermore, he had the right to arm new knights. Should the prior of Saint John have happened to be preceded by the prior of Roncesvalles in any ceremony, this must have been because the latter was required to administer a religious service. Last, but by no means least, the Order of Saint John was by and large considered the shield of the holy Catholic faith, members of which were ready for martyrdom for the sake of the exaltation of their faith. This, according to Berenguer, should have left his precedence out of question.

17 José Goñi Gaztambide, Historia de los obispos de Pamplona, vol. 2, Siglos XIV-XV (Pamplona: Eunsa-Institución Príncipe de Viana, I 979), 85-86. 
The question of who was right naturally arises. To avoid delving into complex theological disputes, which were ultimately out of the scope and interest of both opponents, as well as of the deciding council, a common thread used by both sides sheds plenty of light onto the question, namely the reference both made to past experience or, in other words, the ritual memory of the kingdom.

\section{RituAl MEMORY: CEREMONIAL PRECEDENCE IN ROYAL PUBLIC SPACES}

The ritual memory of medieval Navarre is well documented. The General Charter, which dates back to the early thirteenth century and which compiles customary law, contains specific instructions for rituals that a new king must undergo in order to ascend the throne.$^{18}$ Later on, at the end of the fourteenth century, likely on the occasion of the coronation of Charles III the Noble (I390), a beautifully illuminated codex containing the "Ceremonial of Coronation, Anointing and Exequies of the Kings of England" (Ceremonial de la Coronación, Unción y Exequias de los Reyes de Inglaterra) was brought to Navarre from England and implemented into local protocol. ${ }^{19}$ For their part, pieces of information and even entire descriptions of coronation ceremonies, oaths, acts of government and funerals remain either in accountant records or in proper minutes. However, even though these rituals of power are of interest to scholars due to the amount and quality of sources that describe not only what ceremonies should have looked like, but also what they indeed did look like, ${ }^{20}$ little attention has been paid to formal precedence. Thus, herein, the principal royal rites of passage (coronations and funerals), as well as relevant government acts will be examined in search of clues to the contention between the above mentioned priors.

I8 Fuero General de Navarra (Edición acordada por la Diputación Provincial, dirigida y confrontada con el original que existe en el Archivo de Comptos por Pablo Ilarregui y Segundo Lapuerta), ed. Pablo Ilarregui and Segundo Lapuerta (Pamplona: Imprenta Provincial, i 869), book I, title I, chapters I and II.

19 On the codex see the publication: Eloísa Ramírez Vaquero (ed.), Ceremonial de la Coronación, Unción y Exequias de los Reyes de Inglaterra. Estudios complementarios (Pamplona: Gobierno de Navarra, 2008).

20 Mercedes Osés Urricelqui, "El ritual de la realeza navarra en los siglos XIV y XV: coronaciones y funerales," in Ceremonial, ed. Ramírez Vaquero, 305-32 I. 


\section{CORONATIONS, OATHS AND ACTS OF GOVERNMENT}

First and foremost, the most sumptuous Navarrese ritual likely corresponds to the ceremony of coronation. ${ }^{21}$ According to the Charter, it had to take place in the Cathedral of Our Lady of Pamplona and, although some scholars consider it to be an "essentially lay" ceremony, ${ }^{22}$ it combined both religious and civil rites, the most notable manifestation of which was the auto-accolade of the king, whose "sword is similar to the Cross". ${ }^{23}$ The estate of the Church was, naturally, at the fore of the liturgy, while the nobility, specifically twelve ricoshombres, lifted the monarch on a shield on behalf of the rest of the society, shouting, "Real, real, real" (royal, royal, royal). ${ }^{24}$ Leaving the semantics of each part of the ceremony aside and focusing on precedence and its political implications, it was not insignificant whether a dignitary was among the first or the second estate; being among the prelates meant filing in a solemn procession prior to the coronation. As the Ceremonial instructed:

Hiis debite peractis ordinetur in ecclesia per archiepiscopos, episcopos, abbatem [...] processio in capis sericis [...]. Etenim regni prelatis [...] solum pertinet regi futuro cum processionis solempnitate ocurrere et ipsum in ecclesiam predictam psallendo antedecere ea decantantes qui in receptiones regnum debent decantari. ${ }^{25}$

During the fourteenth and fifteenth centuries, six royal coronations took place, ${ }^{26}$ including that of Jeanne II and Philip III ( 1329$)^{27}$, Charles II ( 1350$)^{28}$, Charles III

21 Osés Urricelqui, “El ritual," 306-3 I 2.

22 José María Lacarra, El juramento de los reyes de Navarra (I234-1329) (Madrid: Real Academia de la Historia, I972), 24; Osés Urricelqui, "El ritual," 306.

23 Fuero General de Navarra, ed. Ilarregui and Lapuerta, book I, title I, chapter I.

24 Ibid.

25 José Luís Sales Tirapu, "Códice B-2 del Archivo y General de Navarra. Transcripción y traducción," in Ceremonial, ed. Ramírez Vaquero, 26 (Source edition).

26 The coronation of Queen Eleanor, wife of Charles III, which took place in I 403, is excluded due to the fact that no minutes but spending records remain, see: José Ramón Castro, Carlos III el Noble, rey de Navarra (Pamplona: Institución Príncipe de Viana, I 967), 209-2 I o; Osés Urricelqui, "El ritual," 306

27 Archivo General de Navarra (1322-1349): I. Documentación real, ed. Ma Teresa Ruiz San Pedro (San Sebastián: Sociedad de Estudios Vascos-Eusko-Ikaskuntza, I 997), nos. 43 and 44; Documentación medieval de Estella (siglos XII-XVI), vol. I, ed. Mercedes Osés Urricelqui (Pamplona: Gobierno de Navarra, 2005), no. 63.

28 Archivo General de Navarra (1349-I38I): I. Documentación real de Carlos II (1349-I36I), ed. Ma Teresa Ruiz San Pedro (San Sebastián: Sociedad de Estudios Vascos-Eusko-Ikaskuntza, I997), no. 3 . 
( 1390$)^{29}$, Blanche and John II ( 1429$)^{30}$, Francis Phoebus ( 1482$)^{31}$ and Catherine of Foix and John of Albret (1494) ${ }^{32}$. The minutes of each ceremony contain a more or less completely described event. Except for the one in 1482 , they all provide information about precedence, which has been gathered in the following table.

Table I: Precedence at coronation ceremonies (1329-1494)

\begin{tabular}{|c|c|c|c|c|c|}
\hline 1329 & 1350 & 1390 & 1429 & 1482 & $\mathbf{1} 494$ \\
\hline $\begin{array}{c}\text { Jeanne II } \\
\text { and Phillip III }\end{array}$ & Charles II & Charles III & $\begin{array}{l}\text { Blanche } \\
\text { and John }\end{array}$ & $\begin{array}{l}\text { Francis } \\
\text { Phoebus }\end{array}$ & $\begin{array}{l}\text { Catherine of Foix } \\
\text { and John of Albret }\end{array}$ \\
\hline Bishop of Pamplona & Bishop of Pamplona & Bishop of Pamplona & Bishop of Pamplona & $\mathrm{n} / \mathrm{d}$ & Bishop of Bayonne \\
\hline Prior of Roncesvalles & Prior of Roncesvalles & Bishop of Tarazona & Bishop of Calahorra & & Bishop of Dax \\
\hline Abbot of Irache & Abbot of Leyre & Bishop of Dax & Bishop of Tarazona & & Prior of Roncesvalles \\
\hline Dean of Tudela & Abbot of Montearagón & Bishop of Calahorra & Bishop of Bayonne & & Abbot of La Oliva \\
\hline Abbot of La Oliva & Abbot of Iranzu & Bishop of Bayonne & Abbot of Montearagón & & Abbot of Leyre \\
\hline Abbot of Leyre & Abbot of La Oliva & Abbot of Irache & Prior of Saint John & & Abbot of Iranzu \\
\hline Abbot of Montearagón & Attorney for the prior & Dean of Tudela & Prior of Roncesvalles & & Abbot of Fitero \\
\hline Abbot of Iranzu & of Saint John & Abbot of Leyre & Abbot of Leyre & & \\
\hline Abbot of Urdax & & Abbot of La Oliva & Abbot of La Oliva & & \\
\hline Attorney for the prior & & Abbot of Iranzu & Abbot of Iranzu & & \\
\hline of Saint John & & Abbot of Fitero & Abbot of Fitero & & \\
\hline & & Abbot of Urdax & & & \\
\hline & & Prior of Saint John & & & \\
\hline Ioth of Io & 7 th of 7 & I 3 th of 13 & 6th of II & $\mathrm{n} / \mathrm{d}$ & Absent \\
\hline
\end{tabular}

Source: Author's elaboration

Absolute preference belonged to the bishops of the dioceses within the Kingdom of Navarre, including Pamplona, Tarazona, Calahorra on the Hispanic side

29 Documentación, I, ed. Osés Urricelqui, no. I 43; Castro, Carlos, 203-208.

30 Eloísa Ramírez Vaquero, Blanca, Juan II y el Principe de Viana (Pamplona: Mintzoa, I986), I 27-I 37; Alberto J. Aceldegui Apesteguía, Blanca I de Navarra (¿1385?-I44I): Consorte, heredera, reina (Pamplona: Sancho el Fuerte Publicaciones, 2014 ), 268 (transcription requires revision - A.D.).

3 I Faustino Menéndez Pidal de Navascués, "La muerte de Francisco Febo, rey de Navarra," Príncipe de Viana, no. 24 I (2007): 42-43.

32 Fidel Fita, "El doctor D. Juan de Jaso, padre de San Francisco Javier: nuevos apuntes biográficos y documentos inéditos," Boletín de la Real Academia de la Historia, no. 23 (1 893): I63-167; Lacarra, Historia, 3: 378-380. 
and Bayonne and Dax on the French side. Regarding the rest of the prelates, their precedence varied: Canons regular of Tudela, Roncesvalles and Montearagón (an abbey in Huesca, customarily linked to Navarre ${ }^{33}$ ), Cistercian abbots of Leyre, La Oliva and Fitero, Benedictine abbot of Irache, Premonstratensian abbot of Urdax and, notably, the prior of Saint John. While Fernando de Egües was partly right when claiming that priors of Roncesvalles used to sit just after the bishops and, if present at all, priors of Saint John used to sit at the very end, there was a substantial change between the coronation of Charles III the Noble in I 390 and the coronation of his daughter Blanche and her husband John II in I 429. There, the Hospitaller prior, Martín Martínez de Olloqui (1383-1435) moved up from the thirteenth and last seat to the sixth and middle seat just behind the bishops and a "foreign" guest from Montearagón, replacing thereby the prior of Roncesvalles. What could have been the reason for this shift?

An examination of precedence in other public ceremonies, such as oaths to and by heirs to the throne ${ }^{34}$ or acts of government during Martínez de Olloqui's tenure, together with an in-depth study of the relationship between this specific prior and the royal family - he was their adviser and ambassador, a frequent guest at the royal table, a tutor to royal children and godfather of their only son, to mention only some elements of his service to the crown ${ }^{35}$ - suggest that even though the institutional position of the Hospitaller prior within the hierarchy of prelates had not been very strong, his personal virtues and skills helped him to climb the ladder on the basis of political and managerial performance. At a time when social networking was as important as it is today, it is also worth mentioning that Martínez de Olloqui was on very good terms with the two subsequent heads of the Navarrese Church, namely Lancelot, vicar general of the diocese of Pamplona ( $1408-1420)^{36}$ and an illegitimate son of King Charles III with María Miguel de Esparza who, after giving birth, became a Hospitaller nun, as well as Sancho Sánchez de Oteiza, dean of Tudela (I 407- I 420) and the bishop of Pam-

33 Antonio Durán Gudiol, "Geografía medieval de los obispados de Jaca y Huesca," Argensola: Revista de Ciencias Sociales del Instituto de Estudios Altoaragoneses, no. 45-46 (1961): I 8 and passim; Carlos Esco Sampériz, El monasterio de Montearagón en el siglo XIII: poder político y dominios eclesiásticos en el Alto Aragón (Huesca: Ayuntamiento de Huesca, Comisión de Cultura, 1987), 22-38 and passim.

34 I 390 - Jeanne (Documentación, I, ed. Osés Urricelqui, nos. I 45 and I 46); 1396 - Mary, Blanche, Beatrix, Isabel (ibid., nos. I 54-159); I 398 - Charles (son) (ibid., nos. I64 and I66); I 402 Jeanne and John of Foix (ibid., no. I 69); Charles (grandson) (ibid., nos. I 87, I 88, I 9 I and I 92 ).

35 Dulska, "Malitia," 260-280.

36 Castro, Carlos, I 88-19 I; Goñi Gaztambide, Historia, 2: 407-467. 
plona (1 $420-1425) .3^{37}$ The latter was linked to the prior by close friendship and was even a proxy for his daughter.

There was only one ceremony where this particular prior sat among the ricoshombres and not among the prelates, that is, the amendment to the General Charter issued by Charles III the Noble in I 4 I $8.3^{8}$ The vicar general Lancelot, the prior of Roncesvalles Sancho de Meoz and the dean of Tudela Sancho Sánchez de Oteiza represented the prelates, while Godofre (another illegitimate son of the king ${ }^{39}$ ), Charles de Beaumont, the lieutenant of the kingdom, Francis de Villaespesa, the chancellor of the kingdom, Martínez de Olloqui, the prior of Saint John, and three noblemen represented the ricoshombres. It is difficult to assess the reason behind this unusual configuration and, although Fernando de Egües highlighted this act and fact as clearly to his advantage in the trial, it was probably an exception based on a specific situation because it is unlikely that it was sign of disfavour towards the Order due to, perhaps, the prior's passiveness during and after the council of Constance. ${ }^{40}$ Rather, it could have been an extraordinary favour towards the Olloqui family as this would have been the first time since 1350 that a representative of this lineage was among this exclusive group. Furthermore, it is also possible that the prior did not attend in his own name, but rather stood in for his cousin and the head of the lineage, Miguel García. ${ }^{41}$

As previously mentioned, the following prior, Juan de Beaumont, who was at the same time the chancellor of the kingdom, gave preference to representing his family in tangled jostling between noble factions which, after the death of Queen Blanche in I44I, led to a civil war that her husband John II and son Charles, Prince of Viana, spearheaded. This was by no means beneficial to the Order of Saint John; one of their priors threw himself into a political conflict in which the Order had no interest and he virtually disassociated himself from being a professed member of the Hospital. In this context, it is understandable that, when later and together with the prior of Roncesvalles, he was appointed counsel-

37 Goñi Gaztambide, Historia, 2: 468-488.

38 Amendment to the General Charter (amejoramiento del Fuero) by Charles III the Noble, I February I 4 1 8, Pamplona, Archivo Real y General de Navarra, Códices, A5, ff. I 57r-i 58 r; transcription can be found in Ensayo histórico-critico sobre la legislación de Navarra, ed. José María de Zuaznavar (Diputación Foral de Navarra: Pamplona, 1966), 662-663, but it omits names of the prelates.

39 Castro, Carlos, I 9 I-I 97.

40 José Goñi Gaztambide, Los obispos de Pamplona del siglo XV y los navarros en los concilios de Constanza y Basilea (Zaragoza: Heraldo de Aragón, I 962); id., Historia, 2: 426-458.

${ }^{41}$ Anna K. Dulska, "Del escudero de Esteríbar al caballero de Rodas. Comienzos de la carrera de Martín Martínez de Olloqui, futuro prior de la Orden de San Juan de Jerusalén en Navarra (s. XIV)," Principe de Viana, no. 26 I, vol. I (2015): 446-447. 
lor of Gaston, Juan de Egües represented the estate of the Church, while Juan de Beaumont did so on behalf of the estate of knights. Unfortunately, the register of Francis Phoebus' coronation in 1482 does not provide information about the prelates or nobles (only some of the ricoshombres that lifted the shield), leaving a gap in history about Juan de Beaumont's presence and possible position at the ceremony.

Table 2: Precedence at oath ceremonies for heirs to the throne

\begin{tabular}{|c|c|c|c|c|c|}
\hline 1390 & 1396 & 1398 & 1402 & 1422 & 1427 \\
\hline Jeanne & $\begin{array}{l}\text { Mary, Blanche, } \\
\text { Beatrix and Isabel }\end{array}$ & Charles & $\begin{array}{l}\text { Jeanne } \\
\left(2^{\text {nd }} \text { time }\right)\end{array}$ & $\begin{array}{c}\text { Charles } \\
\text { (the Prince of Viana) }\end{array}$ & $\begin{array}{l}\text { Ratification } \\
\text { of the Prince } \\
\text { of Viana as heir }\end{array}$ \\
\hline Bishop of Pamplona & Bishop of Bayonne & Bishop of Bayonne & Vicar general of & Bishop of Pamplona & Bishop of Pamplona \\
\hline Bishop of Bayonne & Vicar general of & Vicar general of & Pamplona & Bishop of Calahorra & Prior of Saint John \\
\hline Abbot of Irache & Pamplona & Pamplona & Bishop of Calahorra & Prior of Saint John & Prior of Roncesvalles \\
\hline Prior of Saint John & Abbot of Irache & Abbot of Irache & Bishop of Bayonne & Prior of Roncesvalles & Dean of Tudela \\
\hline Dean of Tudela & Prior of Saint John & Prior of Saint John & Prior of Saint John & Abbot of Irache & Abbot of Irache \\
\hline Prior of Roncesvalles & Attorney of the dean & Prior of Roncesvalles & Abbot of Montearagón & Abbot of Leyre & Abbot of La Oliva \\
\hline Prior of Our Lady of & of Tudela & Prior of Our Lady of & Abbot of Irache & Abbot of La Oliva & Abbot of Leyre \\
\hline Pamplona & Abbot of Urdax & Pamplona & Prior of Roncesvalles & Abbot of Iranzu & Abbot of Iranzu \\
\hline Abbot of La Oliva & Abbot of Fitero & Abbot of La Oliva & Dean of Tudela & Abbot of Fitero & Abbot of Urdax \\
\hline Abbot of Iranzu & & Abbot of Leyre & Abbot of Leyre & Abbot of Urdax & \\
\hline \multirow[t]{4}{*}{ Abbot of Urdax } & & Abbot of Fitero & Abbot of La Oliva & Prior of Our Lady of & \\
\hline & & Abbot of Urdax & Abbot of Iranzu & Pamplona & \\
\hline & & Abbot of Fitero & Abbot of Fitero & Canons of Santa & \\
\hline & & & Abbot of Urdax & María of Pamplona & \\
\hline 4th of IO & 4th of 7 & 4th of I I & 4th of I4 & 3 th of 13 & 2th of 9 \\
\hline
\end{tabular}

Source: Author's elaboration

The next and last coronation in the independent kingdom of Navarre took place in 1494 and left out the Hospitaller prior, Berenguer Sanz de Berrozpe, since he was absent likely due to his obligations at the Central Convent of Rhodes ${ }^{42}$. However, Berenguer, who introduced the priory of Navarre into modernity,

42 Patricia Burgui Fernández, "El priorato navarro de la Orden de San Juan de Jerusalén a finales de la Edad Media. Berenguer Sanz de Berrozpe, I 478 - I 5 I 4" (Unpublished Ph.D. diss., Universidad de Navarra, 20 I 4), 9 I. 
Table 3: Precedence during acts of government

\begin{tabular}{|c|c|c|c|c|c|c|}
\hline 1390 & 1396 & 1398 & 1418 & 1422 & 1423 & 1427 \\
\hline $\begin{array}{l}\text { Appointment of } \\
\text { tutors of infanta } \\
\text { Jeanne }\end{array}$ & $\begin{array}{l}\text { Appointment of tutors of } \\
\text { infantas Mary, Blanche, } \\
\text { Beatrix and Isabel }\end{array}$ & $\begin{array}{c}\text { Appointment of tutors } \\
\text { of infante Charles } \\
\text { (son of Charles III) }\end{array}$ & Amendment to the General Charter & $\begin{array}{l}\text { Appointment of tu- } \\
\text { tors of infante Carlos } \\
\text { (grandson of Charles } \\
\text { III) }\end{array}$ & Privilege of the Union & $\begin{array}{l}\text { Confirmation of tutors of } \\
\text { Charles, prince of Viana }\end{array}$ \\
\hline $\begin{array}{l}\text { Prelates: } \\
\text { Martín de Zalba, } \\
\text { bishop of Pamplona } \\
\text { and chancellor of } \\
\text { the Kingdom } \\
\text { Jimeno de Aibar, } \\
\text { prior of Roncesvalles } \\
\text { Martín Martínez } \\
\text { de Olloqui, prior of } \\
\text { Saint John }\end{array}$ & $\begin{array}{l}\text { Prelates: } \\
\text { Martín de Zalba, cardenal } \\
\text { of Pamplona } \\
\text { Martín Martínez de Ollo- } \\
\text { qui, prior of Saint John }\end{array}$ & $\begin{array}{l}\text { Prelates: } \\
\text { Martín Martínez de } \\
\text { Olloqui, prior of Saint } \\
\text { John } \\
\text { Martín de Sorauren, } \\
\text { prior of Our Lady of } \\
\text { Pamplona } \\
\text { Juan de Roncesvalles, } \\
\text { abbot of Irache }\end{array}$ & $\begin{array}{l}\text { Prelates: } \\
\text { Lancelot of Navarre, vicar general of } \\
\text { Pamplona } \\
\text { Sancho de Meoz, prior of Roncesvalles } \\
\text { Sancho Sánchez de Oteiza, dean of Tudela } \\
\text { Ricoshombres: } \\
\text { Godofre de Navarre } \\
\text { Charles de Beaumont, lieutenant } \\
\text { Francis de Villlaespesa, chancellor } \\
\text { Martín Martínez de Olloqui, prior of } \\
\text { Saint John } \\
\text { Arnalt, lord of Luxa } \\
\text { Beletrán de Lacarra } \\
\text { Pierres de Peralta }\end{array}$ & $\begin{array}{l}\text { Prelates: } \\
\text { Sancho Sánchez de } \\
\text { Oteiza, bishop of } \\
\text { Pamplona } \\
\text { Martín Martínez } \\
\text { de Olloqui, prior of } \\
\text { Saint John } \\
\text { Juan Galindo, prior of } \\
\text { Roncesvalles } \\
\text { Pierres de Peralta, } \\
\text { king's butler }\end{array}$ & \begin{tabular}{|l|} 
Prelates: \\
Sancho Sánchez de \\
Oteiza, bishop of \\
Pamplona \\
Martín Martínez de \\
Olloqui, prior of Saint \\
John \\
Juan Galindo, prior of \\
Roncesvalles \\
Charles de Beaumont, \\
lieutenant \\
Beltran de Lacarra, \\
king's chamberlain \\
Pierres de Peralta, king's \\
butler
\end{tabular} & $\begin{array}{l}\text { Prelates: } \\
\text { Martín de Peralta, bishop of } \\
\text { Pamplona } \\
\text { Martín Martínez de Ollo- } \\
\text { qui, prior of Saint John } \\
\text { Juan Galindo, prior of } \\
\text { Roncesvalles } \\
\text { Pierres de Peralta, king's } \\
\text { butler }\end{array}$ \\
\hline 2nd among prelates & 2nd among prelates & Ist among prelates & 4th among prelates & 2nd among prelates & 2nd among prelates & 2nd among prelates \\
\hline
\end{tabular}

Source: Author's elaboration 
proved his worth as a protector of the Order's interests ${ }^{43}$ and, as the feud with the priors of Roncesvalles demonstrated, he struggled to reclaim his protocol rights.

\section{PRECEDENCE AROUND DEATH}

A royal funeral constituted another exceptional ceremony within the realm's public space. Existing accountant records provide enough information to reconstruct the course of the exequies, ${ }^{44}$ but they are silent in the terms of protocol. According to the Ceremonial, the prince's body was to be accompanied by a funeral procession composed of "prelates and magnates of his kingdom":

[...] princeps adornatus cum regni sui pontificibus et magnatibus, ad locum quxm pro sua sepultura elegerit cum omni reverentia deferetur et cum exequiis regalibus honestissime tradetur sepulture. ${ }^{45}$

However, unfortunately no specific information remains about the precedence within the context of a royal death.

Instead there are two other types of sources that can shed light on this issue. The first one refers to royal testaments. Despite their formal aspects and official character, they reflect the last will (both political and personal) of the testator and provide insight into how the monarch perceived a variety of agents on the political scene as institutions and as individuals. Thus, for example, in both of Charles II's testaments ( 1376 and I 385 ), the Order of Saint John was omitted, while the king expressed deep devotion to Our Lady of Roncesvalles and ordered his entrails to be buried there (his body was laid to rest in the Cathedral of Pamplona, while his heart was buried in the sanctuary of Ujué). ${ }^{46}$

Charles III's I 403 testament ${ }^{47}$ provided alms for Roncesvalles, as well as other monasteries and abbeys; it also requested the prior and chapter to perpetually re-

43 Burgui Fernández, El priorato, 255-258.

44 Castro, Carlos, I 23 - I 27 and 454-457; Osés Urricelqui, "El ritual," 3 I 3-32 I; Julia Pavón Benito, "En la hora de la muerte," in Morir en la Edad Media. La muerte en la Navarra medieval, ed. Julia Pavón Benito and Ángeles García de la Borbolla (Valencia: Universitat de València, 2007), I 5 I- I 78; Julia Pavón Benito, "Exequias regias," in Pamplona y la muerte en el Medievo, ed. Julia Pavón Benito, Julia Baldó Alcoz, and Ángeles García de la Borbolla (Murcia: SEEM-CSIC-Editum, 20 I 3), I 60-I 77; Eloísa Ramírez Vaquero, "Los restos de la reina Blanca de Navarra y sus funerales en Pamplona," Principe de Viana, no. 208 (1 996): 345-358.

45 Tirapu, "Códice," roo (Source edition).

46 Castro, Carlos, I $23-\mathrm{I} 24$.

47 Ibid., 594-605; Documentación, I, ed. Osés Urricelqui, no. I 7 I. 
cite a response de mortuis over the entrails of the king's father every Monday. The Order of Saint John was once more omitted in terms of religious dispositions. Furthermore, should an heir to the throne be under twenty, the prior of Roncesvalles was appointed as one of the regents of the kingdom on behalf of the estate of the Church, while the prior of Saint John was appointed on behalf of the estate of the ricoshombres. The prior of Saint John appeared once more with a substantial, but rather worldly, duty when he was entrusted, together with three other lay knights, with the governorship of present and future infantes (royal children). This meant residing with them in order to educate, advise and protect them. Charles's daughter Blanche later issued a similar stipulation. ${ }^{48}$

Charles III died more than two decades later ( 1425 ). "The lords of the Cortes, prelates and many other peoples" followed his corpse in a procession; he was laid to rest in a spectacular sepulchre sculpted by Johan Lome de Tournai between I 413 and I $419 .{ }^{49}$ Besides the figures of the King and Queen Eleanor (who had died in I 4 I 5), it contains a funeral procession with twenty-eight mourners who represent a circle of the closest courtiers to the monarch. Given their attributes and features, in some cases life-casted, some have been identified with a degree of certainty, including the prior of Saint John, Martín Martínez de Olloqui. ${ }^{5 \circ}$

Thus, this masterpiece of gothic art could be an outstanding source to examine the Hospitaller prior's position among the political elites during this reign. Alas, to the regret of historians and historians of art, during subsequent conservation work (the first of which took place in I 509) the effigies were removed and placed back in different positions without registering the original placement. Notwithstanding, it seems reasonable that, although the sepulchre in its current layout does not help with the question of precedence, the question of precedence, reliably documented and analysed above, may help to establish the order in which Johan de

48 Juan Jesús Virto Ibáñez, "El testamento de la reina Blanca de Navarra. La copia de los Archivos de Pau," Principe de Viana, no. 259 (2014): 140 and 153.

49 R. Steven Janke, Jehan Lome y la escultura gótica posterior en Navarra (Pamplona: Diputación Foral de Navarra-Institución Príncipe de Viana-CSIC, 1977), 82; Clara Fernández-Ladreda Aguadé, "La escultura navarra en tiempos del compromiso de Caspe," Artigrama, no. 26 (20 I I): I 85-242; Clara Fernández-Ladreda Aguadé, "La escultura en Navarra en la primera mitad del siglo XV. Jehan Lome y su círculo," Anales de Historia del Arte, no. 22 (20 I 2): 7-37; Clara Fernández-Ladreda Aguadé, "Escultura. Johan Lome y los talleres coetáneos," in El arte gótico en Navarra, ed. Clara Fernández-Ladreda Aguadé, Javier Martínez de Aguirre Aldaz, Carlos Martínez Álava, and Carmen Lacarra Ducay (Pamplona: Gobierno de Navarra, 2015 ), 5 I 3 - 52 I.

so Anna K. Dulska, "Nostro amado et fiel conceillero: prior sanjuanista en el sepulcro de Carlos III el Noble. Consideraciones iconográficas," in Los espacios del rey. Poder y territorio en las monarquias hispánicas (siglos XII-XIV), ed. Fernando Arias Guillén and Pascual Martínez Sopena (Leioa: Universidad del País Vasco UPV/EHU, 20 I 8), 47 I-488. 
Lome originally placed the effigies of prelates and magnates to immortalise his subject's direct political and personal power environment.

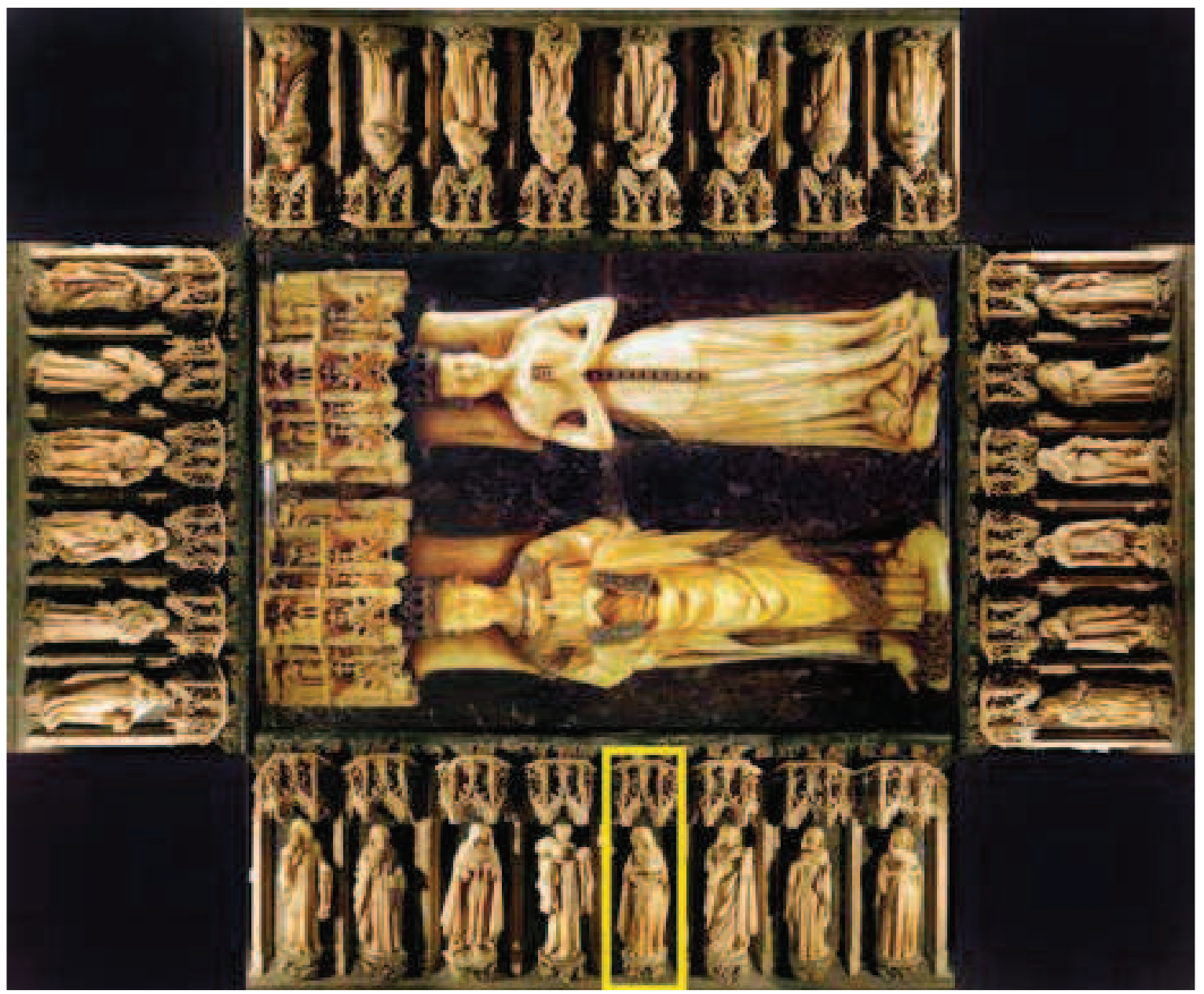

Image I: Sepulchre of Charles III the Noble and the prior of Saint John among the mourners, Courtesy of Clara Fernández Ladreda and Carlos Martínez Álava.

\section{CONCLUSIONS}

Rites, rituals and symbolic behaviours during ceremonies and government acts were far from being "empty ceremonials" ${ }_{51}$ or fossilised routines and had both transcendental and tangible implications for contemporaries. One of them was the place, or the seat, assigned to participants in circles of power, which reflected the order and significance of dignitaries and of the institutions they represented. The feud between the priors of Roncesvalles and Saint John is an eloquent argument

51 Althoff, Die Macht, 199. 
that reflects the importance their seats had to them not only in terms of immediate prestige, but also as a matter of institutional identity. The prior of Roncesvalles' assertion of bishopric insignia and vestment, the discourse about the Order of Saint John being the shield of the Catholic faith, or ritual memories as expressions of a confrontation between an inner and outer perception all epitomise an identitary dialogue. It is worth noting that, while the Order of Saint John clearly considered itself both a religious and military order, its religious condition was not that obvious from outside (kings did not even ask them to pray for their souls), which points toward a certain secularisation of the institution.

Having said that, does precedence answer the question of the Hospitaller prior of Navarre's place among the kingdom's power elites? First of all, it bears mentioning that, independent of its rank, which varied, the Order of Saint John was an integral part of Navarrese ecclesiastical structures, though being a prelate did not necessarily mean being a spiritual lord. The variation in precedence given to prelates can be seen as a sign of an aristocratisation of clergy in that it reflected an ordering of the people in charge of institutions rather than a hierarchy of the institutions themselves. In this sense, the static institutional order admitted a certain pragmatic dynamism based on personal qualities. In this context and from the Hospitaller viewpoint, the key priory was the rule of Martín Martínez de Olloqui, who managed to scale upwards from the very last position to the first after the bishop. Furthermore, assuming that ritual communication in public space reaffirms Kantorowicz's theory of the king's two bodies, ${ }^{52}$ it follows that courtly precedence suggests that the dichotomy of the political and physical body can also be applied to other agents. In this sense, the prior's institutional body was closely related to his personal one. The feedback between them could be beneficial, as in case of Martínez de Olloqui or Sanz de Berrozpe, or harmful, as in case of Beaumont. Either way, the above analysis of precedence confirms the existence of reciprocity between the ritual theatre performed in public spaces and the political backstage. For medieval, high-ranking individuals, gathering to discuss the affairs of the kingdom and, at the same time, looking after their own negotia, not only defined the symbolic hierarchy between them, but also set the scene for political action.

Finally and getting back to the feud herein discussed, the royal council reached a truly Solomonic judgement:

s2 Ernst Kantorowicz, The King's Two Bodies: A Study in Mediaeval Political Theology (Princeton: Princeton University Press, I957). 
"It seems very clear that both dignities and each of them are of great importance, prerogative and honour and both priors have proved many exemptions, prerogatives, liberties, privileges [...] it is doubtful to determine in favour on one side without prejudice and derogation of the other [...] Should both of them meet during a session of the Cortes, they should precede each other among the ecclesiastical arm henceforth alternatively every year".

Since Berenguer Sanz de Berrozpe had sat first most recently, Fernando de Egües was the first to enjoy preference according to the new rule, which derogated the I 499 sentence and seemingly buried the hatchet between the two priors. ${ }^{53}$

\section{PRIMARY SOURCES:}

Madrid. Archivo Histórico Nacional. Órdenes Militares, Carp. 850, nos. 32, 33 and 34. Pamplona. Archivo Real y General de Navarra. Códices, A5, ff. I 57 r- I 58 r.

Roncesvalles. Archivo de la Real Colegiata de Roncesvalles. Dignidad Pr., Fajo Ú., o24, ref. Perg. 446.

Actas de las Cortes de Navarra (1530-I829): Libro I (I530-1608). Edited by Luis Javier Fortún Pérez de Ciriza. Pamplona: Parlamento de Navarra, I 991.

Archivo General de Navarra (1322-I349): I. Documentación real. Edited by Ma Teresa Ruiz San Pedro. San Sebastián: Sociedad de Estudios Vascos-Eusko-Ikaskuntza, I 997.

Archivo General de Navarra (I349-I38I): I. Documentación real de Carlos II (1349-136I). Edited by Ma Teresa Ruiz San Pedro. San Sebastián: Sociedad de Estudios Vascos-Eusko-Ikaskuntza, 1997.

Colección diplomática de Santa María de Roncesvalles (I I27-1300). Edited by Ma Isabe Ostolaza. Pamplona: Institución Príncipe de Viana, I 978.

Documentación medieval de Estella (siglos XII-XVI). Vol. I. Edited by Mercedes Osés Urricelqui. Pamplona: Gobierno de Navarra, 2005.

Ensayo histórico-critico sobre la legislación de Navarra. Edited by José María de Zuaznavar. Pamplona: Diputación Foral de Navarra, i 966.

Fuero General de Navarra (Edición acordada por la Diputación Provincial, dirigida y confrontada con el original que existe en el Archivo de Comptos por Pablo Ilarregui y Segundo Lapuerta). Edited by Pablo Ilarregui and Segundo Lapuerta. Pamplona: Imprenta Provincial, I 869.

Sales Tirapu, José Luís. "Códice B-2 del Archivo y General de Navarra. Transcripción y traducción." In Ceremonial de la Coronación, Unción y Exequias de los Reyes de Ingla-

53 Actas de las Cortes de Navarra (1530-1829): Libro I (I530-I608), ed. Luis Javier Fortún Pérez de Ciriza (Pamplona: Parlamento de Navarra, I99 I), 23 and passim. 
terra: Estudios complementarios, edited by Eloísa Ramírez Vaquero, I 9- I o I (Source edition). Pamplona: Gobierno de Navarra, 2008.

\section{SECONDARY SOURCES:}

Aceldegui Apesteguía, Alberto J. Blanca I de Navarra (¿I385?-I44I): Consorte, heredera, reina. Pamplona: Sancho el Fuerte Publicaciones, 20 I 4.

Althoff, Gerd. Die Macht der Rituale: Symbolik und Herrschaft im Mittelalter. Darmstadt: Wissenschaftliche Buchgesellschaft, 2003.

Althoff, Gerd, Johannes Fried, and Patrick J. Geary (eds.). Medieval Concepts of the Past: Ritual, Memory, Historiography. Cambridge: Cambridge University Press, 2002.

Andrews, Frances. "Ritual and Space: Definitions and Ways Forward." In Ritual and Space in the Middle Ages, edited by Frances Andrews, I -29. Donington: Shaun Tyas, 20 I I. Barquero Goñi, Carlos. "La orden militar del Hospital y la monarquía castellana durante la Baja Edad Media." Meridies. Revista de Historia Medieval, no. 5-6 (2002): I 4 I - I 50. Barquero Goñi, Carlos. "Los Hospitalarios y los últimos reyes de Navarra ( I 483 - I 5 I 2)." In The Hospitallers, the Mediterranean and Europe. Festschrift for Anthony Luttrel, edited by Karl Borhardt, Nikolas Jaspert, and Helen J. Nicholson, 233-242. Aldershot: Ashgate, 2007.

Barquero Goñi, Carlos. "The Hospitallers and the Kings of Navarre in the Fourteenth and Fifteenth Centuries." In The Military Orders. Vol. 2, Welfare and Warfare, edited by Helen J. Nicholson, 349-354. Aldershot: Ashgate, 1998.

Barquero Goñi, Carlos. La Orden de San Juan de Jerusalén en Navarra: siglos XIV y XV. Pamplona: Fundación Fuentes Dutor, 2004.

Bertelli, Sergio. The King's Body: Sacred Rituals of Power in Medieval and Early Modern Europe. Translated by Robert Burr Litchfield, University Park: Penn State Press, 20 I 0. Burgui Fernández, Patricia. "El priorato navarro de la Orden de San Juan de Jerusalén a finales de la Edad Media. Berenguer Sanz de Berrozpe, i 478-i 5 I 4." Unpublished Ph.D dissertation, Universidad de Navarra, 20 I 4.

Castro, José Ramón. Carlos III el Noble, rey de Navarra. Pamplona: Institución Príncipe de Viana, I 967.

Cierbide Martinena, Ricardo. Estatutos antiguos de la Orden de San Juan de Jerusalén: Versión original occitana y su traducción al español, según el códice navarro del AHN de Madrid (I3 I4). Pamplona: Gobierno de Navarra, I 999.

Dulska, Anna K. "Del escudero de Esteríbar al caballero de Rodas. Comienzos de la carrera de Martín Martínez de Olloqui, futuro prior de la Orden de San Juan de Jerusalén en Navarra (s. XIV).” Principe de Viana, no. 26 I, vol. I (201 5): 437-450.

Dulska, Anna K. "Nostro amado et fiel conceillero: prior sanjuanista en el sepulcro de Carlos III el Noble. Consideraciones iconográficas." In Los espacios del rey. Poder y territorio en las monarquias hispánicas (siglos XII-XIV), edited by Fernando Arias Guillén and Pascual Martínez Sopena, 47 I-488. Leioa: Universidad del País Vasco UPV/EHU, 2018. 
Dulska, Anna K. "Malitia temporis. Priorato navarro de la Orden de San Juan de Jerusalén bajo fray Martín Martínez de Olloqui ( 1383 - I 435)." Unpublished Ph.D dissertation, Universidad de Navarra, 20 I 6.

Durán Gudiol, Antonio. "Geografía medieval de los obispados de Jaca y Huesca." Argensola: Revista de Ciencias Sociales del Instituto de Estudios Altoaragoneses, no. 45-46 (1961): I-103.

Esco Sampériz, Carlos. El monasterio de Montearagón en el siglo XIII: poder político y dominios eclesiásticos en el Alto Aragón. Huesca: Ayuntamiento de Huesca, Comisión de Cultura, 1987.

Fernández-Ladreda Aguadé, Clara. "Escultura. Johan Lome y los talleres coetáneos." In El arte gótico en Navarra, edited by Clara Fernández-Ladreda Aguadé, Javier Martínez de Aguirre Aldaz, Carlos Martínez Álava, and Carmen Lacarra Ducay, 5 I 3 - 55 I. Pamplona: Gobierno de Navarra, 20 I 5.

Fernández-Ladreda Aguadé, Clara. "La escultura en Navarra en la primera mitad del siglo XV. Jehan Lome y su círculo." Anales de Historia del Arte, no. 22 (20 I 2 ): 7-37.

Fernández-Ladreda Aguadé, Clara. "La escultura navarra en tiempos del compromiso de Caspe." Artigrama, no. 26 (20 I I): i 85-242.

Fita, Fidel. "El doctor D. Juan de Jaso, padre de San Francisco Javier: nuevos apuntes biográficos y documentos inéditos." Boletín de la Real Academia de la Historia, no. 23 ( 1893$): 67-240$.

García Larragueta, Santos A. "La Orden de San Juan de Jerusalén en Navarra. Siglo XIV." In Las órdenes militares en el Mediterráneo occidental (s. XII-XVIII). Coloquio celebrado los días 4, 5, 6 de mayo de 1983 , edited by Instituto de estudios manchegos (Ciudad Real, Espagne) and Casa de Velázquez (Madrid), I $03-1$ 38. Madrid: Casa de Velázquez, I 989 / Ciudad Real: Instituto de Estudios Manchegos, I 989.

Goñi Gaztambide, José. Historia de los obispos de Pamplona. Vol. 2. Siglos XIV-XV. Pamplona: Eunsa-Institución Príncipe de Viana, i 979.

Goñi Gaztambide, José. Los obispos de Pamplona del siglo XV y los navarros en los concilios de Constanza y Basilea. Zaragoza: Heraldo de Aragón, I 962.

Holger Petersen, Nils, Mette Birkedal Bruun, and Jeremy Llewellyn. The Appearances of Medieval Rituals. The Play of Construction and Modification. Turnhout: Brepols, 2004.

Hunyadi, Zsolt "Entering the Hospital. A Way to the Elite in the Fifteenth Century?" In Élites et ordres militaires au Moyen Âge. Rencontre autour d'Alain Demurger, edited by Philippe Josserand, Luís F. Oliveira, and Damien Carraz, ı o - I I o. Madrid: Casa de Velázquez, 2015.

Ibarra, Javier. Historia de Roncesvalles. Pamplona: Acción Social Tipografía, I 935.

Janke, R. Steven. Jehan Lome y la escultura gótica posterior en Navarra. Pamplona: Diputación Foral de Navarra-Institución Príncipe de Viana-CSIC, I 977.

Kantorowicz, Ernst. The King's Two Bodies: A Study in Mediaeval Political Theology. Princeton: Princeton University Press, 1957.

Lacarra, José María. "Las Cortes de Aragón y de Navarra en el siglo XIV.” Anuario de Estudios Medievales, no. 7 ( I 970/7 I): 645-652. 
Lacarra, José María. El juramento de los reyes de Navarra (I234-1329). Madrid: Real Academia de la Historia, 1972.

Lacarra, José María. Historia politica del Reino de Navarra desde sus origenes hasta su incorporación a Castilla. Vol. 3. Pamplona: Aranzadi, I 973.

Menache, Sophia. The Vox Dei. Communication in the Middle Ages. New York-Oxford: Oxford University Press, I990.

Menache, Sophia. "Elections in the Military Orders in the Late Middle Ages: an Achilles ' Heel?" In Die Ritterorden als Träger der Herrschaft: Territorien, Grundbesitz und Kirche, edited by Roman Czaja and Jürgen Sarnowsky, I 4 I-I 56. Ordines Militares. Colloquia Torunensia Historica XIV. Toruń: Wydawnictwo Uniwersytetu Mikołaja Kopernika, 2007.

Menéndez Pidal de Navascués, Faustino. "La muerte de Francisco Febo, rey de Navarra." Principe de Viana, no. 24 I (2007): 389-398.

Muir, Edward. Ritual in Early Modern Europe. Cambridge: Cambridge University Press, 2000.

Nicholson, Helen J. “Nolite confidere in principibus. The Military Orders' Relations with the Rulers of Christendom." In Elites et ordres militaires au Moyen Age. Rencontre autour d'Alain Demurger, edited by Philippe Josserand, Luís F. Oliveira, and Damien Carraz, 26I-276. Madrid: Casa de Velázquez, 2015.

Osés Urricelqui, Mercedes. "El ritual de la realeza navarra en los siglos XIV y XV: coronaciones y funerales." In Ceremonial de la Coronación, Unción y Exequias de los Reyes de Inglaterra. Estudios complementarios, edited by Eloísa Ramírez Vaquero, 305-32 I. Pamplona: Gobierno de Navarra, 2008.

Pavón Benito, Julia. "En la hora de la muerte." In Morir en la Edad Media. La muerte en la Navarra medieval, edited by Julia Pavón Benito and Ángeles García de la Borbolla, I 5 I-I 78 . Valencia: Universitat de València, 2007.

Pavón Benito, Julia. "Exequias regias." In Pamplona y la muerte en el Medievo, edited by Julia Pavón Benito, Julia Baldó Alcoz, and Ángeles García de la Borbolla, I60-I 77. Murcia: SEEM-CSIC-Editum, 20 I 3.

Pavón Benito, Julia. "Juan de Beaumont, prior del Hospital: promoción al cargo y control de la Orden por parte de una facción nobiliaria." Medievalismo, no. 25 (2015): 369-388.

Pavón Benito, Julia. "La relación entre monarquía y la Orden de San Juan de Jerusalén en Navarra (siglos XII-XV). Un primer análisis.” In La Orden del Hospital de San Juan de Jerusalén. Contextos y trayectorias del Priorato de Navarra medieval, edited by Julia Pavón Benito and María Bonet Donato, I I I - I 77. Pamplona: Eunsa-CSIC, 20 I 3.

Phillips, Simon. The Prior of the Knights Hospitaller in Late Medieval England. Woodbridge: The Boydell Press, 2009.

Ramírez Vaquero, Eloísa (ed.), Ceremonial de la Coronación, Unción y Exequias de los Reyes de Inglaterra. Estudios complementarios. Pamplona: Gobierno de Navarra, 2008.

Ramírez Vaquero, Eloísa. "La comunidad regular de Santa María de Roncesvalles (siglos XII-XIX).” Principe de Viana, no. I 99 ( I 993): 357-402. 
Ramírez Vaquero, Eloísa. “Los restos de la reina Blanca de Navarra y sus funerales en Pamplona." Principe de Viana, no. 208 ( 1996): 345-358.

Ramírez Vaquero, Eloísa. Blanca, Juan II y el Principe de Viana. Pamplona: Mintzoa, i 986.

Ramírez Vaquero, Eloísa. Solidaridades nobiliarias y conflictos politicos en Navarra, I387-1464. Pamplona: Gobierno de Navarra, I 990.

Sarnowsky, Jürgen. "Kings and Priors: the Hospitaller Priory of England in the later Fifteenth Century." In Mendicants, Military Orders and Regionalism in Medieval Europe, edited by Jürgen Sarnowsky, 83- i 02. Aldershot: Ashgate, I 999.

Toomaspoeg, Kristjan. "Les ordres militaires au service des pouvoirs monarchiques occidentaux." In Élites et ordres militaires au Moyen Age. Rencontre autour d'Alain Demurger, edited by Philippe Josserand, Luís F. Oliveira, and Damien Carraz, 32 I-332. Madrid: Casa de Velázquez, 20 I 5.

Vicens Vives, Jaume. Juan II de Aragón (1398-1479): monarquía y revolución en la España del siglo XV. Edición de Paul H. Freedman y Joseph M. Muñoz i Lloret. Pamplona: Urgoiti, 2003.

Virto Ibáñez, Juan Jesús. "El testamento de la reina Blanca de Navarra. La copia de los Archivos de Pau." Principe de Viana, no. 259 (2014): I 3 I - I 58.

Zabalo Zabalegui, Javier. La administración del reino de Navarra en el siglo XIV. Pamplona: Universidad de Navarra, I 973.

Zupka, Dušan. Ritual and Symbolic Communication in Medieval Hungary under the Arpád Dynasty (I000-I30I). Leiden: Brill, 2016. 